\title{
PITX2 wt Allele
}

National Cancer Institute

\section{Source}

National Cancer Institute. PITX2 wt Allele. NCI Thesaurus. Code C75892.

Human PITX2 wild-type allele is located within 4q25-q27 and is approximately $25 \mathrm{~kb}$ in length. This allele, which encodes pituitary homeobox 2 protein, plays a role in both the modulation of transcription and the regulation of pancreatic development. Mutations in the gene are associated with Rieger syndrome type 1, iridogoniodysgenesis type 2 , Peters anomaly, and ring dermoid of cornea. 